\title{
Food: Outlook Favorable for Consumers
}

\author{
NEIL A. STEVENS
}

HE 1977 outlook for food is generally favorable for consumers. Despite damage to certain fruit and vegetable crops last winter, large supplies and relatively stable prices are in prospect for most foods. ${ }^{1}$ This was the forecast of the U.S. Department of Agriculture at its annual outlook conference and in recent releases.

The generally favorable outlook for food this year is in contrast to the years $1973-75$ when sharply reduced supplies and unexpectedly large increases in export demand resulted in sharp increases in domestic food prices. The developments in those years led to a decline in per capita food consumption and an increase in the proportion of disposable income spent for food - both of which were opposite to long-established trends. With two years of large crop harvests as well as an expansion in supplies of livestock foods beginning in late 1975 , consumers are again enjoying a resumption of the long-run movement toward greater per capita food consumption, and a declining proportion of their income spent on food.

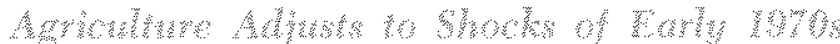

The agricultural sector of the U.S. economy was subjected to a number of disturbances in the early 1970 s which affected the demand for and supply of food. These events included adverse weather conditions both at home and abroad, major realignment of international currencies, embargoes on grain shipments, price and wage controls, and the oil embargo and subsequent large increases in the price of energy. As a consequence smaller quantities of food were produced for domestic consumption, and large increases occurred in food prices.

In the past two years, the food sector has been untangling itself from these destabilizing events. Agricultural production was largely freed from Govern-

\footnotetext{
See U.S. Congress, Senate, Committee on Agriculture and Forestry, 1977 U.S. Agrictilural Outlook, (Papers Presented at the National Agricultural Outlook Conference Sponsored by the U.S. Department of Agriculture, Washington, D.C., November 15-18, 1976, National Food Situation, U.S. Department of Agriculture (March 1977) and Agricultural Out* look, U.S. Department of Agriculture (March 1977).
}

ment production controls in 1973 , and thus has been able to adjust fairly rapidly to the changing market conditions. The enviornment for adjustments in the food industry has been enhanced by the absence of further severe shocks in the past two years. Export demand has stabilized, domestic wage and price controls have been removed, and embargoes have not been used extensively.

Adjustments have occurred in both crop and livestock production. Disappearance of the major crop inventories in 1972 and 1973 , despite relatively high crop production in these years, was followed by considerably higher grain crop prices. Farmers responded to the higher prices by increasing the acreage planted to crops. The total acreage devoted to crops increased over 10 percent from 1972 to 1976 , but overall crop production rose only about 8 percent. The failure of crop production to rise as rapidly as the acreage devoted to crops reflects both somewhat less favorable growing conditions in 1976, and the fact that new land brought into production was generally less productive than land previously in cultivation. Crop production in the past two years, however, has been considerably above the production in the drought-stricken year of 1974.

Major adjustments in the livestock sector have also occurred. Substantially higher feed prices in 1972 led to an interruption in the upward trend in livestock production. Such production declined in 1973, increased somewhat in 1974, but fell again in 1975 as the effects of the 1974 crop failure worked itself through the livestock industry. Feeding operations were cut back and animals were fed and marketed at lighter weights for shorter periods of time. In 1976 total livestock production rebounded as production was stimulated by higher livestock prices and lower feed grain prices, as well as herd liquidation.

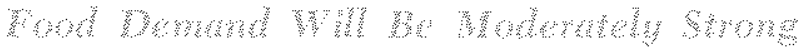 by}

Demand for food is expected to increase in 1977. One important source of fluctuation in growth of de- 
mand for food is the rate of gain in disposable income. Incomes grew somewhat less rapidly in 1976 than many analysts had hoped, but overall, the pace of the recovery and disposable personal income gains have been similar to those of other postwar recoveries." Expansion of disposable personal income is generally expected to continue through 1977 as monetary and fiscal policies have been generally consistent with further economic expansion. Despite the cold weather and natural gas shortages which hampered production in the first quarter, real economic growth is expected to average around 5 percent in $1977 .^{3}$ Thus the demand for domestic food is expected to expand again this year.

Exports are also an important source of demand which greatly influence the domestic food picture, with farm exports now accounting for about 25 percent of U.S. crop production. Export demand has been rising rapidly in recent years as a result of several factors including the realignment of international currencies, some crop failures abroad, growing world population, increased per capita incomes, and the decision of the U.S.S.R. to increase livestock production by importing grain from Western countries in bad harvest years.

Growth of export demand is likely to be slowed somewhat this year by a 10 percent increase in grain production outside the United States. While the value of U.S. agricultural exports is expected to edge above the $\$ 22.8$ billion in fiscal 1976 , the volume of exports is forecast to drop to 99.4 million metric tons from the 107 million metric tons in fiscal 1976.

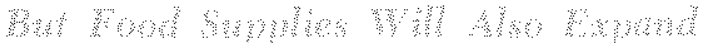

The dominant feature of the food outlook is the supply of livestock and crop foods which has already been produced or now is in the production process. The general outlook is for the production of most foods in 1977 to equal or exceed 1976 levels. This outlook, of course, is subject to the vagaries of weather influences which could substantially alter crop output and animal production patterns.

\section{men Writs}

Crop food supplies for the first half of 1977 have been largely determined by 1976 harvests and stocks

\footnotetext{
"See Neil A. Stevens and James E. Turley "Economic PanseSome Perspective and Interpretation," this Review, Decernber 1976 , pp. $2-7$.

${ }^{3}$ Agricultural Outlook, U.S. Department of Agriculture, January-February 1977 , p. 4 .
}

carried over into the new marketing year. Total crop production of food used for human and animal consumption was the same in 1976 as in 1975 . With substantially larger stocks carried over from the large 1975 harvest, total crop supplies available for consumption this year were boosted above last year's level.

Cereals such as wheat and rice are among the most plentiful crops. Wheat production in 1976 was about the same as the record crop in 1975 and almost 20 percent above 1974. With larger stocks carried over from the previous year, total wheat supplies for the $1976 / 77$ year are almost 10 percent above 1975/76. Hence, wheat supplies are adequate despite the unfavorable crop conditions over much of the winter wheat growing areas during the fall and winter. Rice acreage and production was down last year, but a five-fold increase in carry-in from the previous year has resulted in a 14 percent increase in available sup. plies in $1976 / 77$. Farmers are planning to reduce rice acreage this spring, but even with smaller production, this season's large inventories will keep supplies adequate throughout the year.

Prospects are for a significant increase in supplies of world sugar in 1976/77. The world sugar crop was about 96 million short-tons, up 6 percent from a year earlier. Consumption of sugar is expected to increase less than the increase in production; hence, carryover stocks at the close of the year is likely to be higher and is expected to represent about one-fourth of world consumption. However, the tariff on imported sugar was increased from 62.5 cents per ewt. to $\$ 1.87$ per cwt. last fall and the price of raw sugar is not likely to change much from current levels.

Oil crop supplies are dominated by soybeans. Last year's 18 percent reduction in soybean production has reduced oil supplies for much of 1977. However, increasing lard and cottonseed oil production will partially offset the decline in soybean oil. Currently, favorable soybean prices are expected to boost acreage this spring and with favorable weather conditions, soybean supplies should be somewhat more plentiful by late this year.

Coffee supplies have been sharply reduced as a result of a severe frost in Brazil in 1975 and coffee prices have been rising ever since. The world crop in 1976-77 is estimated at 62 million bags, down from 73 million bags a year ago. Furthermore, coffee production is expected to be hampered for at least another two years as trees recover from the severe freeze and new trees reach maturity. 
Supplies of fresh vegetables were sharply reduced by the severe weather conditions of this past winter as well as reduced acreage of some crops. Florida crops such as tomatoes, peppers, snap beans, cucumbers, and eggplant were severely damaged by a freeze while some other crops such as cabbage, celery, lettuce, escarole, radishes and sweet com escaped much of the damage. In addition, Texas vegetable crops such as cabbage and carrots were reduced due to cold and wet weather conditions as well as planned acreage reductions. As a result of the smaller supplies of fresh vegetables, the fresh vegetable component of the food price index in the first quarter was approximately 20 percent above a year earlier, which translates into approximately a 1 percent increase in grocery store food prices.

Replanted vegetable crops scheduled to be marketed this spring are expected to lead to sharply falling fresh vegetable prices. However, the vegetable situation, both fresh and processed, could be further complicated this summer by lack of irrigation water in some parts of the western states. The impact of the western drought, however, may not be too severe. Current water supplies in the southern California producing areas generally are adequate, while conservation of water supplies and smaller acreages of less valuable crop such as rice, alfalfa and other field crops in other areas will allow the scarce water supplies to be applied to the more valuable vegetable and fruit crops.

Supplies of processed vegetables, measured by stocks of canned and frozen vegetables early this year, are below the relatively high levels of a year ago, but potato supplies are quite large as the fall crop was at a record 300 million cwt. The 1976 dry bean crop was slightly below a year ago but availability of other relatively cheap animal proteins has resulted in the sluggish demand for this crop.

Prospective supplies of fresh and processed fruits are mixed. Citrus crops were expected to be at a record level this year, about 17 percent above last year's record crop. Substantial freeze damage has reduced the Florida citrus production to around 183 million boxes, just slightly above last year's crop. However, the juice yield will be down so that the amount of frozen orange juice from the Florida crop may be 6 to 9 percent below last season. Total citrus production from all producing areas was slightly above the previous season's production.
Thentert $\mathrm{Wmol}$

Production decisions made last year and early this year have insured relatively large supplies of livestock products for the first half of 1977. Supplies of red meats, particularly pork, are expected to remain relatively large in the first half of 1977 , despite unfavorable profit margins for cattle and hog producers last year. Beef production in the first half of the year is expected to be slightly below a year ago, but pork production will likely be one-ffth above year earlier levels and will more than offset the decline in beef output. Broiler production is expected to increase further during the year although less favorable profit margins should slow the rate of gain. Overall livestock production in the first half of the year will likely exceed that of a year ago.

Milk production is expected to remain somewhat above year-earlier levels in the first half of this year. But as was recently pointed out by the Federal Reserve Bank of Chicago, the consumer is not likely to enjoy any gains, in terms of lower milk prices, from the expanding output.

Higher dairy support prices became effective today (April 1, 1977) in line with the recent announcement by the Administration. The increase boosts the support price for manufacturing milk to $\$ 9$ per hundredweight, up from the $\$ 8.26$ level that had prevailed for the past six months and $\$ 8.13$ imposed one year ago. The rise in the support price comes in the face of increasing production, stagnating consumption, and mounting government stocks - trends that will no doubt be reinforced by the higher support prices. ${ }^{4}$

Prospects for livestock production for the second half of 1977 are for increases in pork production to slow as lower hog prices than a year ago will tend to discourage farmers from rapidly increasing farrowings this spring. By the fourth quarter of 1977 pork production may be 4 to 6 percent above the relatively high fourth quarter of 1976 . Beef output is expected to taper off later this year to about 6 to 8 percent below a year ago. Beef output will be constrained by a reduced inventory which early this year stood 6.8 percent below the level of two years ago. Broiler and egg production is expected to make only moderate gains in the second half of the year. On balance, livestock production in the second half of the year is expected by the U.S.D.A. to fall somewhat below year ago, however, production for the entire year will likely average slightly above last year.

^See Gary L. Benjamin, Federal Reserve Bank of Chicago Agricultutal Letter (April I, 1977). 


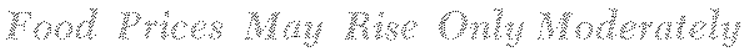

Rising food prices were of great national concern in 1973 and 1974 as these prices rose more rapidly than prices of other goods and service. Retail food prices increased over 14 percent in both 1973 and 1974, while retail prices of items other than food increased 3.9 and 9.9 percent, respectively. This situation has reversed in the past two years with more abundant food supplies and a slower growth in export demand. Retail food prices increased 8.5 percent in 1975, slightly less than the 9.3 percent increase for items other than food. In 1976 food prices increased only 3 percent over 1975 , about one-half the rate of increase of other retail prices. Domestically produced foods purchased at grocery stores rose only about $1^{1 / 4}$ percent in 1976 . Imported foods and food eaten away from home contributed the remainder of the higher cost of food last year.

Food prices will likely rise less rapidly than other prices this year. Although winter damage to vegetable crops, along with greater than seasonal increases in prices of coffee, eggs, and fish has increased the food costs early this year, large supplies for most foods will keep food price increases at a moderate level. Some of the large increases in food prices early this year, particularly fresh vegetables, should prove temporary, as these prices are expected to decline sharply with

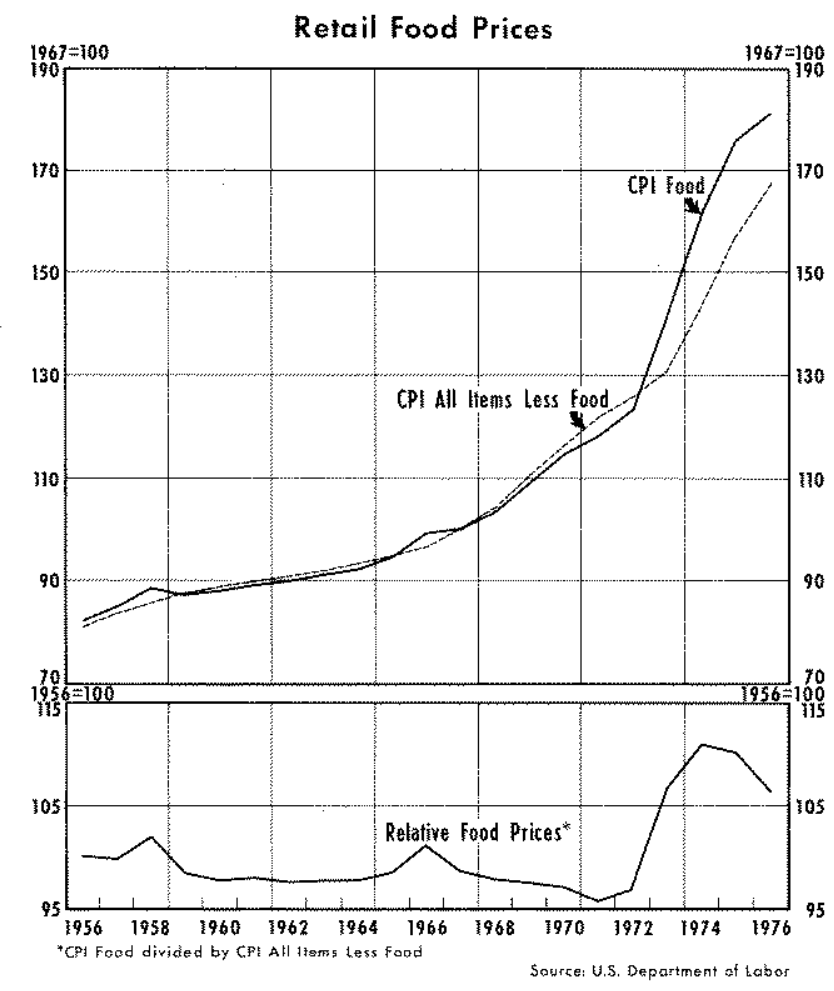

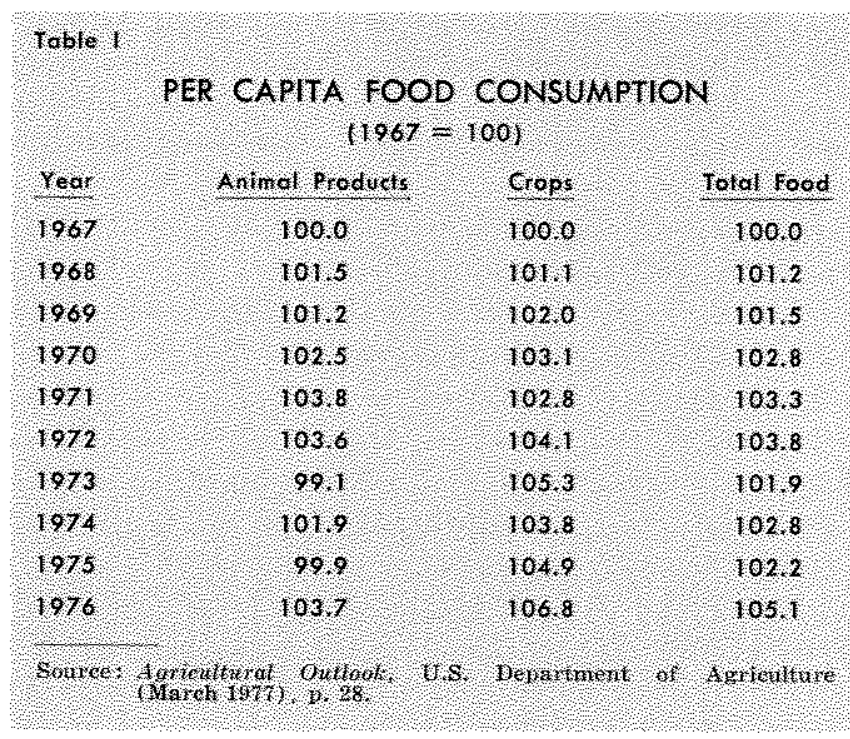

the harvesting of spring vegetables. The U.S. Department of Agriculture projects that retail food prices at grocery stores for all of 1977 will average 3 to 5 percent higher than in 1976. Also, contributing to an increase in overall retail food prices will be price increases for food eaten away from home. Such prices may rise somewhat more than grocery store prices, possibly around 6 percent. Increased prices of coffee, fishery products, and other imported foods are expected to account for approximately one-half of the rise in retail food prices this year. The remainder will be associated with higher marketing margins as average farm prices will likely remain unchanged from a year ago.

This range for food prices reflects varying assumptions of weather conditions. The 5 percent estimate takes into account some possible underestimation of the impact on prices from the bad weather this winter as well as problems which could result from continued drought conditions in the West. Drought in livestock producing areas could alter the pattern of livestock prices as forced liquidation of herds would lower prices around mid-year followed by higher prices later this year. On the other hand, the 3 percent projection assumes more favorable weather conditions during this year's growing season resulting in large crop harvests both in the U.S. and abroad.

As a result of the favorable price and supply conditions for food last year, per capita consumption of food rebounded sharply from 1975. U.S. per capita consumption of all foods increased almost 3 percent in 1976 with the strongest gain coming from animal products. But per capita consumption of crop food also made gains (Table I). Per capita consumption of 
FEDERAL RESERVE BANK OF ST. LOUIS

然

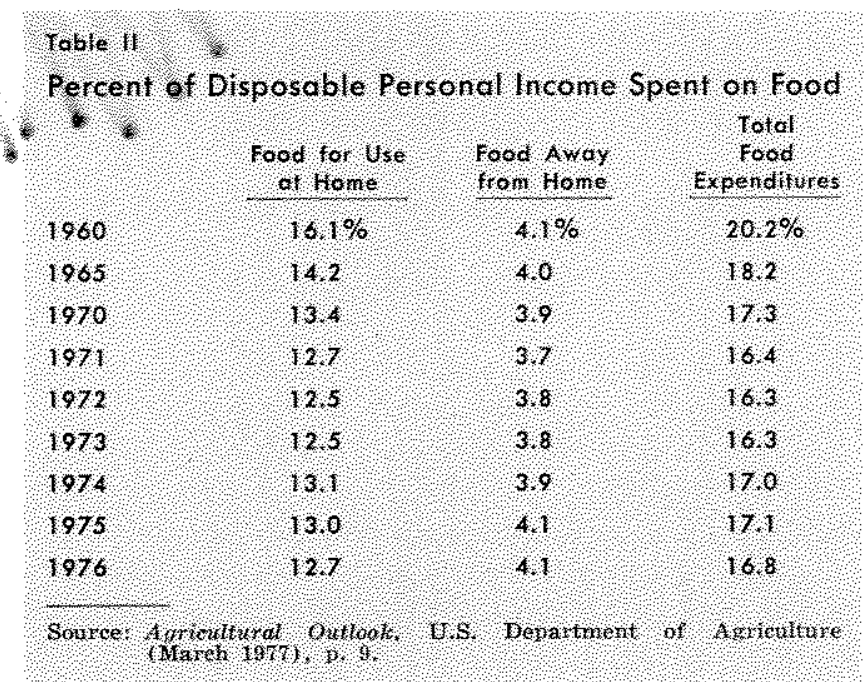

food is likely to make some further gains this year although the increase will likely be less than in 1976 .

Not only did U.S. consumers buy more food, but they spent a smaller percent of their disposable income on food in 1976 than a year earlier. Table II shows that U.S. consumers from 1960 through 1972 spent less and less of their income on food. Consumers spent 16.8 percent of their income on food last year, down from 17.1 percent in 1975 , but still higher than the 16.3 percent in 1972 . The percent of total disposable income spent on food this year will probably be slightly less than last year.

\section{Sumpary}

Food prices in 1976 rose less rapidly than the overall inflation rate in contrast to the 1973-75 period. Consumers found that they spent a smaller percentage of their income on food while buying increased quantities. This favorable situation resulted from increased supplies as normal weather conditions, relatively free pricing, removal of production controls, and lack of other shocks to the agricultural economy led to significant gains in production.

The reasonably good crop harvest in 1976, and livestock production already in progress assures fairly large supplies of food, at least in the first half of 1977. The staple foods such as cereal crops, livestock foods, potatoes, and sugar are in plentiful supply. On the other hand, several fruit and vegetable items, fishery products, and coffee are in short supply. However, supplies of most vegetables are expected to return to normal this spring. On balance, relatively large supplies of food are expected to limit increases in grocery store food prices to around 3 to 5 percent during 1977.

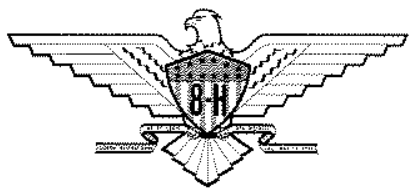

